\title{
Seasonality: Is it a problem or challenge facing future tourism employment? Implications for management
}

\section{Aleksandra Grobelna ${ }^{1}$ (D), Katarzyna Skrzeszewska²}

\begin{abstract}
Many countries have recently seen rapid growth in tourism which is perceived as an engine for economic growth and social development. On the other hand, many countries have been faced with problems of attracting and retaining well-qualified employees, as many graduates do not enter the tourism industry on graduation. This study aims to determine the attitudes of Tourism and Hospitality (T\&H) students towards the problem of seasonality in tourism employment and how it relates to students' employment aspirations. The research was conducted among students of higher educational institutions (HEI) located in Northern Poland (Southern Baltic Sea Region). A survey instrument was applied and 171 usable questionnaires were retrieved and analyzed in this study. Students' perceptions of tourism seasonality seem to be more positive than negative and it may relate to their working intentions on graduation. Additionally, students who declared their seasonal working experience referred to tourism seasonality more positively. This study makes useful contributions to the existing knowledge and management literature by showing that the ability to identify negative aspects of future career development, such as tourism seasonality, and the ability to manage it effectively, may have a positive impact on employment perception in the view of a future workforce.

Keywords: Southern Baltic Sea Region, tourism, seasonality, employment aspirations, students.
\end{abstract}

\footnotetext{
1 Aleksandra Grobelna, Ph.D., Gdynia Maritime University, 81-87 Morska str., 81-225 Gdynia, Poland, e-mail: a.grobelna@wpit.umg.edu.pl (ORCID ID: 0000-0002-1765-6757).

2 Katarzyna Skrzeszewska, Ph.D., Gdynia Maritime University, 81-87 Morska str., 81-225 Gdynia, Poland, e-mail: k.skrzeszewska@wpit.umg.edu.pl (ORCID ID: 0000-0002-2102-0313).
} 


\section{INTRODUCTION}

The influence of travel and tourism (T\&T) on economic and social development is indisputable as it opens up countries to business, trade and capital investment opportunities leading to new jobs and entrepreneurialism for the workforce (World Travel \& Tourism Council, 2015b). During recent years $T \& T$ has been growing at a faster rate than both the general economy and other significant sectors including automotive, financial services or health care (World Travel \& Tourism Council, 2015b). In 2016 T\&T's contribution to world GDP generated US\$7.6 trillion (10.2\% of global GDP) and supported 292 million jobs ( 1 in 10 jobs) (World Travel \& Tourism Council, 2017b). T\&T's expansion is forecast to continue (World Travel \& Tourism Council, 2015b) and the total T\&T GDP is forecast to constitute $11.4 \%$ of global GDP by 2027 (World Travel \& Tourism Council, 2017b).

Taking a direct perspective, T\&T's direct contribution to GDP grew by $3.1 \%$ in 2016 (generating US\$2.3 trillion), i.e. faster than the global economy as a whole (growth at 2.5\%), and is predicted to increase at an average of 3.9\% per year over the next ten years. When it comes to T\&T's direct contribution to employment, it rose by $1.8 \%$ in 2016 (supporting 109 million jobs globally), which means that almost 2 million net additional jobs were generated by T\&T directly. However, it is expected that by 2027 T\&T will support more than 380 million jobs worldwide, which means 1 in 9 of all jobs in the world, and the sector is expected to contribute circa $23 \%$ of total global net new jobs over the next ten years (World Travel \& Tourism Council, 2017b).

Based on the above, it can be argued that as one of the world's largest economic sectors, tourism can be perceived as a major source of employment (Lu \& Adler, 2009). However, although it creates new jobs, drives exports, and generates prosperity across the whole world (World Travel \& Tourism Council, 2017a), the T\&T sector also experiences talent gaps and deficiencies as indicated in the World Travel \& Tourism Council's report prepared by Oxford Economics (World Travel \& Tourism Council, 2015a). The overwhelming number of countries analyzed in the report were forecast to have deficit talent trends over the next decade (talent demand grows faster than talent supply).

Similarly, in the case of Poland, although T\&T directly supported 305,000 jobs in this country in 2016 (1.9\% of total employment) and is forecast to increase to 405,000 jobs (2.5\% of total employment) in 2027 (World Travel \& Tourism Council, 2017a), Poland is among the countries that are projected to have the most acute deficit T\&T talent trends that can touch the college/ university level in particular (World Travel \& Tourism Council, 2015a). Additionally, poor transfer of tourism graduates to the industry is observed, as over half of the graduates (54.7\%), as indicated in a report commissioned 
by the Ministry of Sport and Tourism of the Republic of Poland (ACTIVE Group, 2014), were not working in consistence with their study profile, which makes the issue of tourism graduates employment a critical topic for both business and educators.

It is underlined that T\&T has some unique characteristics that make it a challenging sector to recruit and retain talent and skills, and among many of these characteristics the seasonal nature of work is emphasized (World Travel \& Tourism Council, 2015a). Employment demands in tourism (particularly in hospitality) often reflect the customers' seasonal and leisure demands (see Kamari, 2004), which means that it is often difficult to offer full-time employment as in other sectors (World Travel \& Tourism Council, 2015a). Thus, unsurprisingly, the workforce here often involves temporary, seasonal, part-time or shift workers (Kamari, 2004; Kusluvan, 2003). These employment features, including seasonal jobs and their instability, may have a negative influence on students' vocational attitudes (see Grobelna \& Marciszewska, 2016a; Jiang \& Tribe, 2009).

On the other hand, peaks in demand create a real opportunity for seasonal employment of young people, particularly T\&H students. It is underlined that seasonal fluctuations in many businesses in the tourism industry seem to promote student employment opportunities at times suitable for both employers and employees (Martin \& McCabe, 2007). Students should be particularly welcomed by the service industry in view of high labor costs and huge fluctuations in demand (Barron, 2007; Barron \& Anastasiadou, 2009). Industry practitioners should appreciate the flexibility and other benefits that young, multitasking, cheap and intelligent seasonally working students (Barron, 2007; Barron \& Anastasiadou, 2009) may bring to their organizations. In a study by Lucas and Ralston (1996), answering the question "Why do you employee students?" employers indicated, among other answers: "to meet increased demand at a particular time" or "to cover for regular staff shortfalls during vacations." Thus, understandably, students as temporary employees seem to be particularly important for the industry (Shin \& Lee, 2011). Their seasonal working experience, perceived as an introduction to the real world of work, may influence students' perception of tourism seasonality and employment aspiration in the industry. This seems to be of great importance, especially that, although tourism industry development can create new employment opportunities (Roney \& Öztin, 2007), attracting and recruiting graduates seems to be a critical issue for the future success of an industry that experiences a shortage of skilled and well-qualified employees (Băltescu, 2016; Tan et al., 2016).

Thus, research on T\&H students' employment aspirations and their critical antecedents is particularly advisable. Given the low status of industry employment, 
due to seasonality and instability of many tourism jobs, the perception of tourism seasonality and its consequences for employment, and particularly in view of the industry's future workforce, this calls for empirical attention.

Based on the above, the objective of this study is to present T\&H students' attitudes towards the problem of seasonality in tourism employment. The aim of the research is to answer the following research questions:

Q1: May students' perception of seasonality in tourism employment relate to their own employment aspirations in tourism after graduation?

Q2: may students' seasonal working experience have an influence on their attitudes towards seasonality in tourism employment?

The following hypotheses are proposed:

H1: That a negative perception of seasonality in tourism employment decreases T\&H students' employment aspirations in tourism.

$\mathrm{H} 2$ : That a positive perception of seasonality in tourism employment increases T\&H students' employment aspirations in tourism.

$\mathrm{H} 3$ : That there is a relationship between students' seasonal working experience in tourism and their perception of seasonality in tourism employment.

The research value of this study may result from the fact that although there are many previous studies that have examined students' perception of the T\&H industry, empirical research focusing specifically on the issue of perceived seasonality in relation to students' employment aspiration is limited, especially within the context of the Southern Baltic Region. Thus this study provides a new perspective on students' perceptions of employment in the T\&H industry taking the case of Central-East Europe. The results of this study aim to be of great importance to the industry which suffers from a low employment status and experiences chronic shortage of skilled and well-qualified employees.

\section{LITERATURE REVIEW}

\section{The concept of tourism seasonality}

The concept of seasonality is defined differently, depending on the science that deals with the essence of seasonality. In economic terms, seasonality is associated with revenue that has not been achieved because business activity is reduced or ceased altogether in certain periods. BarOn's work (1975), 
which identifies the basic components of seasonality and the importance of cyclicality in the creation of demand for tourism services, is the foundation for the study of the nature of seasonality in tourism.

There is no universally accepted definition of seasonality. Although the essence of this phenomenon is that, with a certain regularity, greater or lesser interest in a given tourist region or tourist attraction occurs, many researchers of this issue propose definitions which focus on different aspects. These definitions can be sorted using classifications based on the essence criterion referred to by the authors of the definition. In general, definitions can be grouped into three areas: (i) seasonality symptoms, (ii) seasonal outcomes, and (iii) the preferences of tourists determining their demand for broadly-defined tourism services (Figure 1).

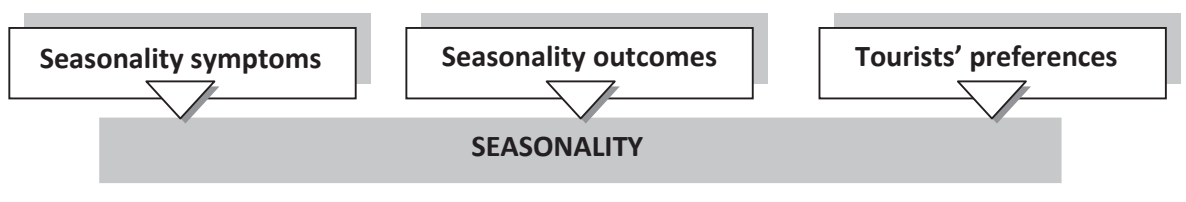

Figure 1. Approach to seasonality definitions - three perspectives

In Butler's definition (1994; 2014), the emphasis is on seasonality, which is a "temporal imbalance in the phenomenon of tourism, which may be expressed in terms of dimensions of such elements as numbers of visitors, expenditure of visitors, traffic on high-ways and other forms of transportation, employment and admissions to attractions". Similarly, Bender, Schumacher and Stein (2005) argue that seasonality is the yearto-year variation associated with specific periods, and Biedermann (2008) describes seasonality as "a prevalent characteristic in travel and tourism marked by sharp variations in demand depending on the time of the year." More specifically, the seasonality characteristics were mentioned by Wall and Mathieson (2006), who in their definition pointed out the recurring yearly cycle: "the peak season and the off season that are separated by two shoulder seasons." Some authors point out cycles shorter than yearly, with varying intensity of visits: month, week, or even a single day (Holloway, 1994; Lundberg, Krishamoorthy, \& Stavenga, 1995). With reference to the definitions regarding the effects of seasonality, Hylleberg should be quoted (1992), who argues that seasonality is not necessarily a regular, repetitive change over the year that directly and indirectly affects business. The third group refers to a particular seasonality - the tourists and their preferences. Thus seasonality is defined as a phenomenon caused by the periodic movement of people 
(Chung, 2009). Tourism demand expresses regular fluctuations associated with seasons (Cooper, Wanhill, Fletcher, Gilbert, \& Fyall, 2008). Although the cited definitions concerned different collections depending on the essence of seasonality raised by the authors, it is difficult to unequivocally and categorically classify the definitions, due to the relationship between the tourists' preferences, seasonality and its effects.

\section{Antecedents and consequences of seasonality - the critical impact on tourism employment}

In literature, two sources of natural and institutional seasonality are most often identified (Butler, 2001; Commons \& Page, 2001; Goulding, Baum, \& Morrison, 2004; Hartmann, 1986). Natural factors are due to the geographic location of both the destination and the origin of the tourists. Not all natural phenomena are the source of seasonality. According to Witt and Moutinho (1995), unpredictable incidents (droughts, floods, volcano eruptions, earthquakes, etc.) are unlikely to occur in the orderly and repetitive seasonal pattern. The most elementary natural factors determining the seasonality include temperature, sunshine, occurrence or absence of precipitation: rain/ snow. There is no one well-established standpoint on the stability of these factors. Koenig-Lewis and Bischoff (2005) believe that they are predictable and permanent because of their small-scale changes. The opposite approach (Baum \& Lundtorp, 2001) states that natural occurrence is less obvious and less predictable in the face of climate change (Baum \& Lundtorp, 2001; Butler, 2000; Butler \& Mao, 1997). Natural factors play a particularly important role in coastal tourism and those types of tourism that are linked to outdoor activity. Institutional factors are those derived from law, politics or traditions, the social preferences created e.g. by social pressure, fashion. These include: (i) time off work and holiday/holidays (Commons \& Page, 2001; Goulding et al., 2004; Hylleberg, 1992), (ii) travel habits and motivations for travel (social pressure, fashion, tradition, inertia, changing tastes) (Commons \& Page, 2001; Goulding et al., 2004), (iii) events (cultural, religious, sports, etc.) (Baum \& Lundtorp, 2001).

The effects of seasonality are extensive, and hence full identification requires a proper classification. The first, most obvious criterion is the nature of the effect, including positive (Draktos, 1987; Hartmann, 1986; Witt \& Moutinho, 1995). There are definitely many more negative effects (e.g., Baum, 1998; Bender, Schumacher, \& Stein, 2007; Butler \& Mao, 1997; Cellini \& Rizzo, 2012; Goulding et al., 2004; Higham \& Hinch, 2002). Another division of effects goes between supply and demand. In this article, due to its subject and purpose, the effects of seasonality on the supply side will be presented. 
Generally, there are three groups of effects caused by seasonality: economic, ecological and socio-cultural. The bigger the volume of tourist activity, the greater the meaning of its effects (Yan \& Wall, 2003).

Among the ecological impacts, the most significant are: seasonal congestion, greater noise and environmental pollution associated with the handling of more people and the tourists' behavior (Butler, 2001) as well as excessive consumption/depletion of local natural resources (Bender et al., 2007). Socio-cultural impacts include increased congestion, increased risk of adverse events (thefts, robberies, acts of terrorism), increased risk of traffic accidents, mass accidents, etc. An increased number of people staying in a given location for a short time may negatively affect the residents' way of life (Jang, 2004). The imbalance in earning income during the year may motivate the emigration of a local population (especially young people), resulting in a deficit of social capital, lower quality of life, especially in the peripheral communities to industrial centers, where tourism plays the most important role.

Major economic effects include: irregular annual income, low return on capital, high investment risk, difficulties with annual fixed costs, shortages in supply during the peak season, unused capacity off season (BarOn, 1975; Baum, 1998; Bender et al., 2007; Butler, 1994; Butler \& Mao, 1997; Cellini \& Rizzo, 2012; Goulding et al., 2004; Higham \& Hinch, 2002; Kizielewicz \& Luković, 2015). Among the economic factors, human factors are worth discussing separately. They are critical for the hotel industry, which is the largest part of the tourism industry. Due to the relatively rigid supply of accommodation, the effects of seasonality are felt in this industry particularly strongly. Not surprisingly, one of the reasons for employees' leaving is seasonality and the part-time nature of employment in this industry (Kusluvan, 2003). High turnover rates (Ko, 2012; Sims, 2003) may be particularly costly for organizations (Tesone, 2010) leading to many negative consequences, such as increases in stress, heavy workload, low employees' morale, poor standards, low productivity and others (see Kusluvan, 2003; Sims, 2003), and finally negatively affecting the organization's competitive advantage (Özbağ, Ceyhun, \& Çekmecelioğlu, 2014).

However, particularly worrying is the fact that the nature of the tourism industry, including its seasonality, determines students' perception of the industry's attractiveness (see Grobelna \& Marciszewska, 2016a; Jiang \& Tribe, 2009). For example, Jiang and Tribe's study results (2009) revealed that the nature of tourism jobs does not encourage students in China to consider the industry as a long-term career. According to the study participants, seasonality was perceived as a factor that may have an important influence on employees' lifestyle, income, etc. (see Jiang \& Tribe, 2009). Similarly, in the case of Polish 
students, one of the identified obstacles to working in tourism after graduation was the perceived seasonality of tourism jobs (Grobelna \& Marciszewska, 2016a). Therefore, "if today's students are to become tomorrow's effective tourism practitioners" (Huang, 2013), the nature of tourism jobs, particularly the issue of seasonality, needs further investigation not only to increase revenues from tourism through extending the high season, but also to increase the inflow of well-educated and trained employees.

\section{Polish coast of the Baltic Sea - its climate and seasonality}

The Polish coast of the Baltic belongs to three voivodships - in the nomenclature of European statistics, to three units at the NUTS2 level. These are Zachodniopomorskie (West Pomeranian) (PL42), Pomorskie (Pomeranian) (PL63) and Warmińsko-Mazurskie (Warmia and Mazury) Voivodships (PL62).

The Warmia and Mazury Voivodship has the least marine character only 4 municipalities (NUTS5) out of 109, i.e. less than $4 \%$, lie directly on the Baltic Sea. It should be noted that in this voivodship tourism is important, but it is more connected with the lakes in the central part of the voivodship than with coastal tourism (Studzieniecki, 2016).

In the Pomeranian Voivodship, about $22 \%$ of gminas (25 out of 114 NUTS5 units) are communes directly adjacent to the Baltic Sea (the open sea or the Bay of Gdansk). Yearly almost twice as many tourists per 1 inhabitant visit this area. The proportions in the West Pomeranian Voivodship are similar - 22 out of 106 NUTS5, i.e. almost 21\%, are communes on the Baltic coast (the open sea or the shallow Pomeranian Bay). There are more than 2.5 tourists per 1 inhabitant per year (GUS Szczecin, 2016).

The Polish climate is not conducive to maintaining high demand for tourist services in the coastal strip throughout the year. Poland is located in a temperate warm zone with a transitional climate, which depends on the direction of the incoming air masses thus acquiring the characteristics of the sea or the continental climate. The location in the temperate zone (between $49^{\circ}$ and $55^{\circ}$ ) of the northern latitude has a strong influence on the variation in length of the day and the degree of insolation per year (Mizerski \& Żukowski, 2014). This results in 6 thermal seasons, which differ in average temperatures and the degree of insolation (Kożuchowski, 2014).

The parallels of geographic regions and the predominance of lowland areas are conducive to the free exchange of air masses from the Atlantic (humid air masses) and from the land areas of Eastern Europe and Asia (dry air masses). The coast of Poland remains under the influence of the Baltic Sea (Kondracki, 2014). The consequence of the free exchange of air masses is the high frequency of variations in weather patterns and precipitation. The 
consequence of the above air temperature and precipitation distributions is the uneven distribution of tourists choosing the Polish Baltic Sea coast as a resting place (Figure 2 ).

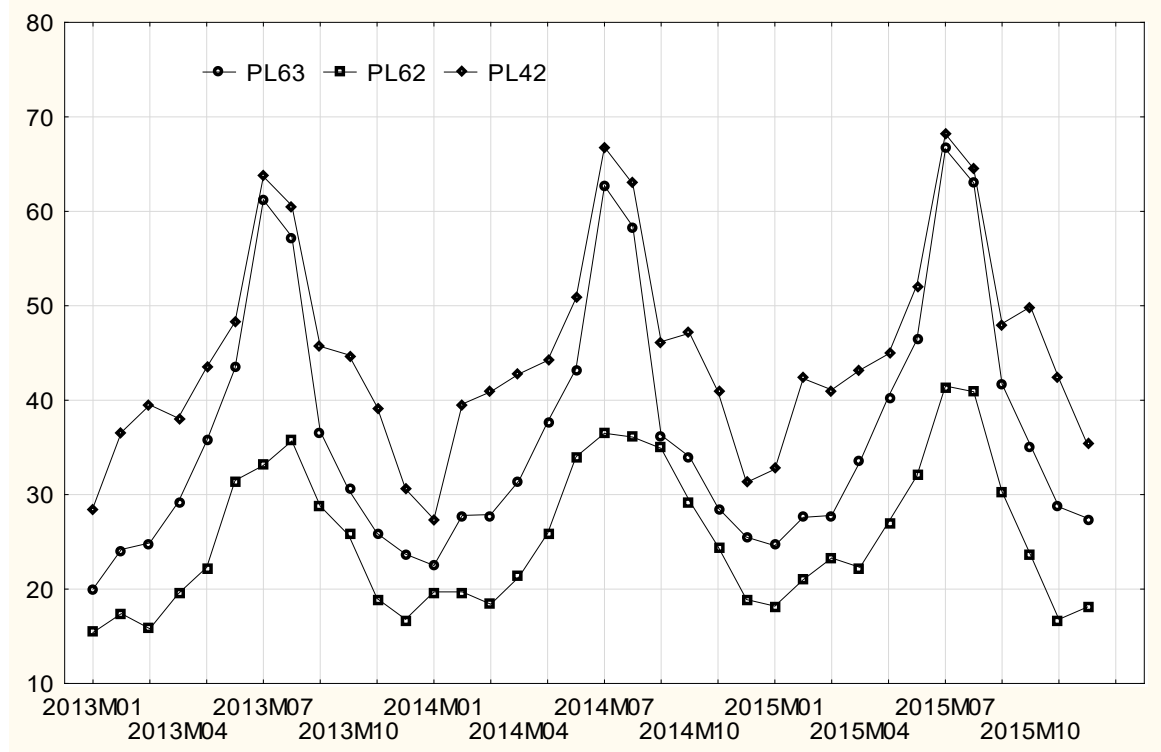

Figure 2. Occupancy rate of bed places in tourist accommodation establishments in coastal areas (PL42, PL62, PL63) by month, in 2015 [\%] Source: (GUS Szczecin, 2016)

By analyzing the changes in occupancy rates, it is clear that in the case of the Pomeranian and West Pomeranian Voivodships, variability is a perfect fit in (Wall \& Mathieson, 2006). It is easy to highlight the clear peak season (July-August) and off-season (December-February) separated by shoulder seasons: March-June and September-November. Research on the causes of this phenomenon reveals that the strongest determinants are natural factors, especially climatic ones, with which the rhythms of tourists' arrival coincide.

\section{RESEARCH METHODS}

\section{Procedure}

In order to obtain the most adequate assessment of seasonality as a factor determining the decision to start a job in tourism, the study was conducted on a sample selected in purposive sampling. In Tricity, studies in the field of 
tourism and recreation are conducted at five higher education institutions (GUS Gdańsk, 2017). The empirical research was conducted among students of three higher educational institutions (HEI) between May and June of 2017. These three HEl were identified as the target group for this study due to their availability. They were chosen due to mutual cooperation and/or familiarity between the researchers and these HEI.

On the basis of data from the statistical yearbook Education in Pomeranian Voivodship in the 2016/2017 school year, the number of graduates in the field of "tourism and recreation" graduating from university (1st and 2nd degree studies) was estimated in 2017 for all universities altogether (GUS Gdańsk, 2017). The number of graduates amounted to 703 people. At $95 \%$ confidence interval, the sample size should be around 250 people (exactly 248). The authors decided to distribute more questionnaires than the required number (+10\%). A total of 275 questionnaires were distributed adequately, to three participating HEls. In this study, the auditorium survey technique has been applied to gather the data. Respondents were requested to fill in the questionnaires during their teaching time agreed with lecturers. Students were informed that their participation was voluntary and that anonymity was protected. The survey was conducted after an explanation of its objectives. A total of 171 usable questionnaires were finally retrieved, yielding a response rate of $62.18 \%$.

All HEI were located in the Tricity metropolis as a part of the Pomeranian Voivodship, which is perceived as a tourist (coastal) destination of Northern Poland and a big academic center. The strength of Tricity is due to the potential of the three cities that make up the metropolis of Gdansk, Gdynia and Sopot. Analysis of the level of economic development of the coast indicates that the Tricity region is the most developed part of the Polish coast. Statistics of national accounts (NUTS3 level) show that while regions with a coastline have lower ratios compared to the national average (NUTSO) and even to the voivodship average (NUTS2), the Tricity area has 30-40 percentage points better results than the national average and 40-50 p.p. better than the voivodship average (Bank Danych Lokalnych, 2017).

These characteristics justify the choice of Tricity as a research location area. On the one hand, tourist attractiveness of Tricity may contribute to creating many new working places, specifically during the summer season. On the other hand, perceived as a big academic center, it may represent educational programs typical of T\&H (Grobelna \& Marciszewska, 2016b). 


\section{Measure}

In developing the research instrument to evaluate students' perception of seasonality in tourism employment, 14 items were finally employed. They derived from the tourism and hospitality employment characteristics illustrated in the literature review and were developed during consultations with academicians and industry practitioners. Additionally, both authors' professional knowledge and expertise related to the T\&H industry and observed trends in the T\&H labor market also contributed to the shape of the items.

Finally, the list of 14 items was divided into two convenience categories that relate positively ( 7 items) and negatively ( 7 items) to the issue of seasonality in tourism employment; they were defined accordingly as Positive Perception of Seasonality (P_PS) and Negative Perception of Seasonality ( $\mathrm{N}_{-}$ PS) in tourism employment.

Students' employment aspirations (EMP_ASP) were measured via four (4) items from (Teng, 2008), who has used them successfully to measure hospitality employment aspirations among post-internship undergraduate hospitality seniors in Taiwan. However, because in this study the employment aspiration variable referred to the students' commitment to the tourism industry in general, the items were reworded accordingly. Additionally, to ensure the translation quality of the items, the back-translation method was applied. Respondents were asked to rate each item according to the extent to which they agree with it, from (1) strongly disagree to (5) strongly agree. Demographic data were also collected.

The reliability alpha used to check the internal consistency of the items within the study constructs were as follows: 0.80 for EMP_ASP; 0.63 for $N_{-}$ SP; and 0.60 for P_SP. Although both N_SP and P_SP had alpha below the recommended value of 0.7 (Nunnally, 1978), they were retained as even lower values of alpha are still considered to be sufficient in the early stages of an exploratory study (Kwok, Adams, \& Feng, 2012; Tepeci \& Bartlett, 2002).

The results were analyzed statistically. To verify the relationship between the study's constructs, Pearson's correlation was applied. To test for significant differences between the study's responses, an independentsamples t-test was used. 


\section{RESULTS}

\section{Respondents' characteristics}

Female respondents accounted for the majority (81.3\%) of all the surveyed students. $52 \%$ of the respondents were in the age range of $22-25$ years, whereas $39.8 \%$ were between $18-21$ years old, the remaining subjects (8.2\%) were older than 25 years. Study respondents mostly came from Poland (89.5\%); a small percentage of students came from Ukraine $(5.8 \%)$ and Norway (1.2\%), the remaining ones were from Russia, Belarus and Ireland. More specifically, most of the study respondents (80.7\%) came from coastal provinces or lake districts where tourism, particularly the seasonal one, is well developed, giving them the unique possibility to observe actively this kind of tourism and its consequences for regional development and the regional labor market. Unsurprisingly, many of the study participants (69.6\%) also declared they had seasonal working experience in tourism. Students were seasonally working in a variety of tourism branches such as food and beverage services $(48.8 \%)$, hospitality services (34.9\%), and travel agencies (5.8\%). Study participants also declared working as a tour guide $(2.9 \%)$ and in transport services (2.9\%), and others. Moreover, $81.9 \%$ of study respondents agreed that work in tourism is connected with uneven distribution of the workload throughout the year.

The above data show that the investigated group, having rich observation and/or experience of the seasonality in tourism employment, may provide adequate feedback on the seasonality problems in tourism employment under investigation in this study.

\section{Seasonality perception and its outcomes for students' employment aspirations}

Analyzing the students' perception of the seasonality impact on tourism employment, the results showed that, generally, more students agree that seasonality contributes positively rather than negatively to tourism employment. Descriptive statistics for the study variables are provided in Table 1 and Table 2.

Among the detailed positive items (Table 1), students agree the most that the seasonal nature of tourism employment generally has many positive aspects, allows getting a job easily during study time, holidays, the summer season, etc., and may be perceived as a source of employees' creativity 
and many innovative solutions as its consequences that reduce the scale of seasonal employment's negative effects on the tourism business.

Table 1. Perception of seasonality in tourism employment - positive aspects. Variable means and standard deviations

\begin{tabular}{lllllllll}
\hline & P_PS & $\mathbf{1}$ & $\mathbf{2}$ & $\mathbf{3}$ & $\mathbf{4}$ & $\mathbf{5}$ & $\mathbf{6}$ & $\mathbf{7}$ \\
\hline Mean & 3.32 & 4.10 & 3.22 & 3.13 & 3.70 & 3.65 & 2.48 & 2.99 \\
St. dev. & 0.51 & 0.88 & 0.99 & 1.02 & 0.91 & 0.75 & 1.00 & 1.01 \\
\hline $\mathrm{N}=171$ & &
\end{tabular}

$\mathrm{N}=171$

Note: P_PS (Positive Perception of Seasonality); seasonality of tourism employment:

1. allows getting a job easily during study time, holidays, the summer season, etc.

2. does not negatively affect the continuity of employment of people with a university diploma

3. does not negatively influence job perception in the tourism industry

4. has many positive aspects including increased interest in tourism employment

5. is a source of employees' creativity and many innovative solutions as its consequences which reduce the scale of seasonal employment's negative effects on the tourism business

6. does not threaten work-life balance

7. does not make it difficult to find a stable job.

Analysis of negative aspects of seasonality in tourism employment revealed that respondents achieved the highest agreement on the statement that it reduces interest in working in tourism industry, decreases attractiveness of employment in tourism and has a negative impact on all job positions in tourism enterprises regardless of the management level (Table 2).

Table 2. Perception of seasonality in tourism employment - negative aspects. Variable means and standard deviations

\begin{tabular}{lllllllll}
\hline & N_PS & $\mathbf{1}$ & $\mathbf{2}$ & $\mathbf{3}$ & $\mathbf{4}$ & $\mathbf{5}$ & $\mathbf{6}$ & $\mathbf{7}$ \\
\hline Mean & 2.68 & 3.20 & 2.62 & 2.84 & 2.79 & 2.21 & 2.70 & 2.39 \\
St. dev. & 0.53 & 1.12 & 0.99 & 0.99 & 1.01 & 0.87 & 0.95 & 0.80 \\
\hline
\end{tabular}

$\mathrm{N}=171$

Note: N_PS (Negative Perception of Seasonality); seasonality of tourism employment:

1. makes tourism perceived as a temporary profession rather than a place for pursuing a long-term career

2. reduces interest in working in the tourism industry

3. decreases the attractiveness of employment in the tourism industry

4. negatively affects all job positions regardless of the level of management

5 . is a source of only negative phenomena

6. hampers employees' innovative initiatives

7. negatively influences all operators in the industry, regardless of the quality of service.

As depicted in Figure 3, correlations among the study constructs were significant and in the predicted directions. More specifically, the results of this study demonstrated that there is both a significant and positive correlation between P_PS and EMP_ASP and a significant negative correlation between 
N_PS and EMP_ASP.In otherwords, the more students believe that seasonality in tourism positively contributes to tourism employment, the stronger their intentions to enter the tourism industry. This provides support for Hypothesis 1. By contrast, the more negatively students perceive seasonality in tourism employment, the lower their commitment to the industry. Thus, Hypothesis 2 was also supported by empirical findings.

H1:

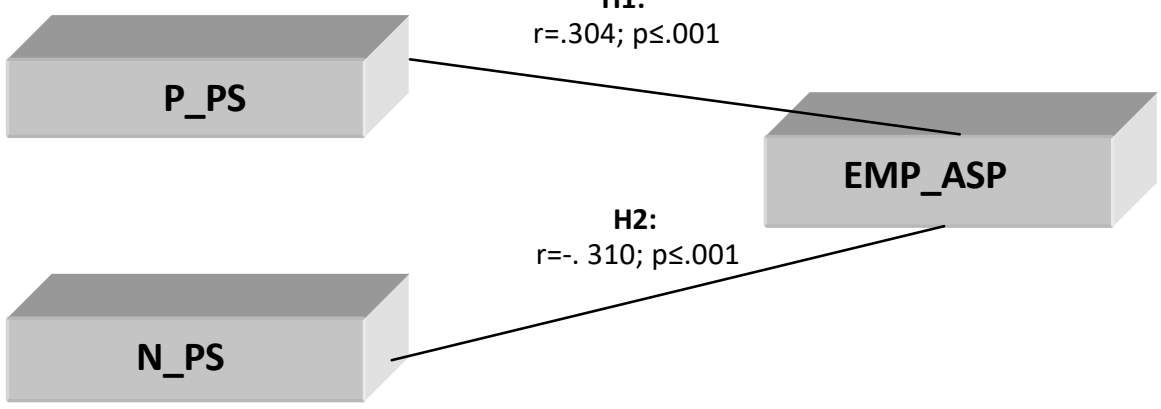

N=171; Note: N_PS (Negative Perception of Seasonality); P_PS (Positive Perception of Seasonality); EMP_ ASP (Employment Aspirations)

Figure 3. Perception of seasonality in tourism employment and its relation to students' employment aspirations in tourism industry upon graduation

Given the detailed level of correlation analyses, it should be noted that the presented relationships, similarly as above, are statistically significant but rather weak. However, it is worth noticing that the strongest positive correlation was observed between EMP_ASP and the perception of seasonality as not making it difficult to find a stable job (item $7 ; r=.252 ; p \leq .001$ ). It means that the more students believe that seasonality does not create obstacles to finding a stable job, the more they feel likely to take a tourism job after graduation (Table 3). Similarly, students who believe that seasonality does not negatively affect the continuity of employment of people with a university diploma (item 2), has many positive aspects including increased interest in tourism employment (item 4) being also a source of employees' creativity and innovative solutions (item 5), are more likely to take tourism jobs after graduation. 
Table 3. Correlations between perception of seasonality in tourism employment - positive aspects - and students' employment aspirations - detailed analyses ${ }^{a}$

\begin{tabular}{llllll}
\hline & $\mathbf{2}$ & $\mathbf{4}$ & $\mathbf{5}$ & $\mathbf{7}$ \\
\hline EMP_ASP & Pearson & $.217^{* *}$ & $.185^{*}$ & $.156^{*}$ & $.252^{* *}$ \\
& $\begin{array}{l}\text { correlation } \\
\text { Sig. (2-tailed) }\end{array}$ & .004 & .016 & .042 & .001 \\
& $\mathrm{~N}$ & 171 & 171 & 171 & 171 \\
\hline
\end{tabular}

* Correlation is significant at the 0.05 level (2-tailed);

${ }^{* *}$ Correlation is significant at the 0.01 level (2-tailed)

Note: EMP_ASP (Employment Aspirations); 2,4,5,7: the same description as in footnotes of Table 1; a only significant correlations are presented in the table above

By contrast, when analyzing the negative aspects of seasonality in tourism employment, the strongest negative correlation is observed among students' EMP_ASP and their perception that seasonality decreases interests in tourism employment (item 2; $r=-.367 ; p \leq .001$ ) (Table 4). Additionally, it is also worth noting that respondents who believe that seasonality leads to tourism being perceived as a temporary profession (item 1), decreases the attractiveness of employment in tourism (item 3 ) and is a source of only negative phenomena (item 5), also displayed less commitment to the tourism industry as a place of future employment.

Table 4. Correlations between perception of seasonality in tourism employment - negative aspects, and students' employment aspirations - detailed analyses ${ }^{a}$

\begin{tabular}{llllll}
\hline & & 1 & 2 & 3 & 5 \\
\hline EMP_ASP & Pearson & $-.159^{*}$ & $-.367^{* *}$ & $-.198^{* *}$ & $-.203^{* *}$ \\
& $\begin{array}{l}\text { correlation } \\
\text { Sig. (2-tailed) }\end{array}$ & .038 & .000 & .010 & .008 \\
& $\mathrm{~N}$ & 171 & 171 & 171 & 171 \\
\hline
\end{tabular}

* Correlation is significant at the 0.05 level (2-tailed);

${ }^{* *}$ Correlation is significant at the 0.01 level (2-tailed)

Note: EMP_ASP (Employment Aspirations); 1-3; 5: the same description as in footnotes of Table 2; a only significant correlations are presented in the table above

Thus going further, it was decided to investigate whether students' seasonal working experience in tourism may have an impact on their perception of tourism seasonality, particularly whether seasonality of tourism employment may reduce significantly the interest in working in the tourism industry. As a result, a statistically significant difference was observed between the analyzed variables ( $t=-1.983 ; p=0.049$ ). Those students who did not have seasonal working experience in tourism significantly more often believed that seasonality in tourism decreases peoples' interests in working 
in the industry, whereas those with working experience in tourism did not have such a determined attitude toward this aspect. Thus, Hypothesis 3 gains support from the empirical data. Probably, having seasonal working experience, students' might gain a real perception of the industry and its work specifics. This, indeed, may lead students to have a more favorable view on tourism employment, particularly given its seasonal nature.

\section{DISCUSSION AND CONCLUSION}

This study was designed to investigate T\&H students' attitudes towards seasonality in tourism employment and its impact on students' tourism employment aspirations. The decision to apply results to the whole population is based on the specificity of the region. In the seaside region, the mass tourism model is still a $3 \mathrm{~S}$ model (sea, sun, sand); therefore, seasonality plays a decisive role in creating demand for tourism industry services. The above statement is based on the results of research on the preferences of both Europeans and Poles. 46\% of Europeans indicate "sunlight and life on the beach" as the preferred way of spending time (EC Press Release Database, 2014). As the most desirable way of spending free time, Poles indicate sunbathing and relaxing in the bosom of nature $(45 \%$ and $41 \%$ respectively) (Borodako, 2016). Perhaps this is one of the reasons for treating the Pomeranian Voivodship as the most desirable destination (in 2014, 2015, 2016) (CBOS, 2017).

The way of spending free time and the preferred destination explains why seasonality is a phenomenon that strongly affects the functioning of the hotel industry in the Pomeranian Voivodship. An additional factor that will probably soon be reinforced by this phenomenon is climate change, because "it's expected that in the future tourists may rely more on last-minute bookings, once they are more certain that the weather in their preferred destination is appealing" (Pang, McKercher, \& Prideaux, 2013).

The study findings revealed that students' perception of seasonality in tourism employment may relate to their employment aspiration after graduation. Thus, students who had more positive attitudes toward the issue of seasonality in tourism employment were more likely to work in tourism upon graduation. By contrast, the more they believed that seasonality in tourism is a source of negative aspects in employment, the less commitment to the industry they displayed. Additionally, over the half of the investigated students declared their seasonal working experience in tourism. Those with such experience referred to seasonality in tourism employment more positively than others, as they were less convinced that seasonality in tourism 
may decrease interest in tourism employment. This proves that students' early seasonal working experience makes them more aware of the reality of tourism jobs and has an influence on their attitudes towards the future careers in the industry.

Taken above, it can be concluded that seasonality in tourism may be perceived in a more favorable light, as a challenge rather than a problem facing tourism employment in the opinions of its future workforce.

The results may be influenced by the fact that Tricity and its immediate surroundings, despite experiencing seasonality in tourism, do not experience such adverse effects as peripheral areas. Due to the nature of individual cities forming a metropolis, Tricity, besides mass tourism services, offers business tourism, medical tourism and wellness \& spa services. Therefore, for young respondents, students of Tricity's $\mathrm{HEl}$, the issue of seasonality, despite its existence, is not a problem that affects their view of future employment and career development in tourism. Moreover, given the statement that the higher level of education may guarantee better job opportunities in the future (Waśniewska \& Olszewska, 2016), students may not perceive job seasonality as a serious threat to their future career development in tourism.

In accordance with the study recommendations, it must be noted that although employees and their competences - especially knowledge - are the main determinant of the development of each organization and its innovativeness (Szelągowska-Rudzka, 2014), one of the industry's concerns is the fact that the tourism and hospitality industry fails to retain significant numbers of well-qualified graduates (Băltescu, 2016; Lam \& Ching, 2007). It is emphasized that youth are particularly poorly committed to the organization in the long run (see, e.g. Choi, Kwon, \& Kim, 2013). Also, previous study results show that it is difficult to say that tourism and hospitality students are committed to a career in the industry (e.g., Richardson, 2008). Thus, in order to attract and retain young people to start their career in the industry, practitioners should realize that students' first working experience, usually gained seasonally, may play an important role in forming and bridging their expectations, playing an important role as a means of learning about the real world situations. Accordingly, it is crucial to realize what young people expect from their work and provide them exactly with what they seek to encourage them to stay in the industry upon graduation and transfer their valuable skills there.

It is pointed out that for young people fast promotion (advancement), development of new skills and work-life balance are of great importance (Ng, Schweitzer, \& Lyons, 2010). They seek creative challenges and they want to have an immediate impact and responsibility. Particularly, those studying tourism and/or hospitality emphasize that self-achievement, congruence 
of work with personal values and open communication are important (e.g., Lewis, 2015). They rank an enjoyable, interesting job, colleagues that they can get along with or pleasant working environment particularly highly (Richardson \& Butler, 2012; Richardson \& Thomas, 2012; Sibson, 2011). Therefore, it is important to design working conditions in such a way so as to provide working students with positive experiences (Richardson, 2008). Students who work seasonally in the industry while studying should have a real chance to deal with meaningful tasks and train in various departments or business sectors in tourism (see Richardson, 2008). They should experience interesting and challenging work that provides them with an opportunity for their own growth and development. Otherwise, when graduates are given menial and boring tasks rather than exciting and worthwhile ones, they may not benefit from the experience; as a result, they are not likely to be interested in developing their careers in the industry at all (Richardson, 2008).

There is no doubt that most students are interested in getting an interesting job during their studies (Suwa, 2014). Although, as indicated in previous research, some students may perceive that the seasonality of tourism work can make it difficult to find a stable job (Aksu \& Koksal, 2005; Kusluvan \& Kusluvan, 2000; Richardson, 2008; Richardson \& Thomas, 2012), seasonality may indeed bring, as indicated by these study results, numerous advantages in students' perception. Especially, it allows getting a job easily during study time, holidays, summer season, etc. Seasonal work may provide a genuine possibility to gain real, beneficial working experience by students during their study time. It is especially important, as students' working experience may have a great impact on their attitudes towards working in industry after graduation (Chen \& Shen, 2012; Kusluvan \& Kusluvan, 2003) and significantly shape their image of a career in tourism (Roney \& Öztin, 2007). Thus, if the industry would not like to miss its chance to attract a young qualified workforce, the most important thing is to perceive seasonal working students as future valuable employees who are worth investing in today in an effort to make them keen to stay in the field for longer. By contrast, if seasonal working students are perceived as only part-time, temporary workers who are not encouraged to gain skills which they can successfully use in their future careers in tourism, they will work today and be gone tomorrow pursuing other avenues for their future employment than tourism.

Therefore, both educators and industry practitioners should tightly cooperate with each other to shape students' realistic expectations towards their work and to assure the high quality of their seasonal work experience; as such experience may strongly influence young people's employment perceptions. Due to the nature of the study, the results cannot be generalized. Additionally, fairly low values of the correlation coefficients 
require interpreting the study results with some caution. However, keeping above, these study results may serve as a basis for discussion and direction for future research with both a larger sample size and more HEI, from different regions, involved in the research project to overcome these limitations and validate the study results.

It may also support researchers in their further efforts to discover more general factors which may affect the perception of the seasonality and in understanding how they may differ, if at all, between different regions of Poland. It would also be useful to extend this study and determine the perceptions of both educators and industry professionals on the problem of seasonality in tourism employment and how they assess its potential influence on young people's career perception of the industry. The potential gaps between the perspectives of academia, business, and students may provide useful insights into the issue of seasonality in tourism employment and persuade all parties to closer cooperation on this issue.

\section{References}

ACTIVE Group. (2014). Losy absolwentów szkół i uczelni kształcqcych kadry dla turystyki. Raport z badań. Ministerstwo Sportu i Turystyki. Retrieved from https://www.gov.pl/documents/292437/436728/Badanie+los\% C3\%B3w+absolwent\%C3\%B3w+2014.pdf/4771aa91-7d29-5dde-828b$5 \mathrm{~b} 013 \mathrm{~d} 4 \mathrm{caOdc}$

Aksu, A.A., \& Koksal, C.D. (2005). Perceptions and attitudes of tourism students in Turkey. InternationalJournal of Contemporary HospitalityManagement, 17(5), 436-447. https://doi.org/10.1108/09596110510604869

Băltescu, C.A. (2016). Graduates' willingness to build a career in tourism. A view point of the students in the tourism profile academic programmes from the Transilvania University of Braşov. Annals of the "Constantin Brâncuşi” University of Târgu Jiu, (3), 36-39.

Bank Danych Lokalnych. (2017). Retrieved from https://bdl.stat.gov.pl/BDL/start BarOn, R.V. (1975). Seasonality in Tourism: A Guide to the Analysis of Seasonality and Trends for Policy Making. London: The Economist Intelligence Unit Limited.

Barron, P. (2007). Hospitality and tourism students' part-time employment: Patterns, benefits and recognition. The Journal of Hospitality Leisure Sport and Tourism, 6(2), 41-54. https://doi.org/10.3794/johlste.62.150

Barron, P., \& Anastasiadou, C. (2009). Student part-time employment: Implications, challenges and opportunities for higher education. International Journal of Contemporary Hospitality Management, 21(2), 140-153. https://doi.org/10.1108/09596110910935642 
Baum, T. (1998). Responding to seasonality in peripheral destination. Insights, 9(107-115). https://doi.org/10.1002/(SICI)1522-1970(199909/10)1:5<299::AIDJTR198>3.0.CO;2-L

Baum, T., \& Lundtorp, S. (2001). Seasonality in Tourism. Oxford: Elsevier.

Bender, O., Schumacher, K.P., \& Stein, D. (2005). Measuring seasonality in central Europe's tourism - how and for what? In M. Schrenk (Ed.), 10th International Conference on Information \& Communication Technologies (ICT) in Urban Planning and Spatial Development and Impacts of ITC on Physical Space (pp. 303-309). Wien: Technische Universität.

Bender, O., Schumacher, K.P., \& Stein, D. (2007). Landscape, seasonality, and tourism: A survey with examples from Central Europe. In H. Palang, $\mathrm{H}$. Sooväli, \& A. Printsmann (Eds.), Seasonal Landscapes (Vol. 7, pp. 181213). Dordrecht: Springer Netherlands. https://doi.org/10.1007/1-40204990-0 8

Biederman, P.S. (2008). Travel and Tourism: An Industry Primer (1st ed.). New York, NY: Pearson Education Limited.

Borodako, K. (2016). Zachowania Polaków na krajowym rynku turystycznym w 2015 r. In J. Berbeka (Ed.), Zmiany zachowań turystycznych Polaków $i$ ich uwarunkowań w latach 2006-2015 (p. 108). Wyd. Uniwersytetu Ekonomicznego w Krakowie.

Butler, R.W. (1994). Seasonality in tourism: Issues and problems. In A.V. Seaton (Ed.), Tourisms: The State of Art (pp. 332-339). Chichester: Wiley.

Butler, R.W. (2000). Seasonality. In J. Jafari (Ed.), Encyclopedia of Tourism (pp. 521-522). London: Routledge.

Butler, R.W. (2001). Seasonality in tourism: Issues and implications. In T. Baum \& S. Lundtorp (Eds.), Seasonality in Tourism (pp. 5-22). Oxford, UK: Elsevier Science.

Butler, R.W. (2014). Addressing seasonality in tourism: The development of a prototype. Paper pesented at the Punta del Este Conference.

Butler, R.W., \& Mao, B. (1997). Seasonality in tourism: Problems and measurement. In P. Murphy \& P. Murphy (Eds.), Quality Management in Urban Tourism (pp. 9-24). Chichester: Wiley.

CBOS. (2017). Wyjazdy wypoczynkowe Polaków w 2016 roku i plany na rok 2017. Komunikat z badań (No. 24). Retrieved from https://www.cbos.pl/ SPISKOM.POL/2017 //K_024_17.PDF

Cellini, R., \& Rizzo, G. (2012). Private and public incentive to reduce seasonality: A theoretical mode. Economics: The Open-Access, OpenAssessment E-Journal, 6(2012-43), 1-33. https://doi.org/10.5018/ economics-ejournal.ja.2012-43

Chen, T.-L., \& Shen, C.-C. (2012). Today's intern, tomorrow's practitioner?-The influence of internship programmes on students' career development in the hospitality industry. Journal of Hospitality, Leisure, Sport \& Tourism Education, 11(1), 29-40. https://doi.org/10.1016/j.jhlste.2012.02.008

Choi, Y.G., Kwon, J., \& Kim, W. (2013). Effects of attitudes vs experience of workplace fun on employee behaviors: Focused on 
Generation $\mathrm{Y}$ in the hospitality industry. International Journal of Contemporary Hospitality Management, 25(3), 410-427. https://doi. org/10.1108/09596111311311044

Chung, J.Y. (2009). Seasonality in tourism: A review. E-Review of Tourism Research (ERTR), 7(5), 82-96.

Commons, J., \& Page, S. (2001). Managing seasonality in peripheral tourism regions: The case of Northland, New Zealand. In T. Baum \& S. Lundtorp (Eds.), Seasonality in Tourism (pp. 153-172). Elsevier. https://doi. org/10.1016/B978-0-08-043674-6.50013-1

Cooper, C., Wanhill, S., Fletcher, J., Gilbert, D., \& Fyall, A. (2008). Tourism: Principles and Practice. Harlow: Pearson Education Limited.

Draktos, C.G. (1987). Seasonal concentration of tourism in Greece. Annals of Tourism Research, 14(4), 582-586. https://doi.org/doi. org/10.1016/0160-7383(87)90075-2

EC Press Release Database. (2014). Tourism expected to grow again in 2014, led by strong domestic and European demand. EC Press Release Database. Retrieved from http://europa.eu/rapid/press-release_IP-14-144_en.htm

Goulding, P.J., Baum, T., \& Morrison, A. J. (2004). Seasonal trading and lifestyle motivation: Experiences of small tourism businesses. Journal of Quality Assurance in Hospitality \& Tourism, (5), 209-238. https://doi. org/10.1300/J162v05n02_11

Grobelna, A., \& Marciszewska, B. (2016a). Undergraduate students' attitudes towards their future jobs in the tourism sector: Challenges facing educators and business. In D. Vasilenko \& N. Khazieva (Eds.). Proceedings of the 4th International Conference on Management, Leadership and Governance (pp. 138-145). London: Academic Conferences and Publishing International Limited.

Grobelna, A., \& Marciszewska, B. (2016b). Work motivation of tourism and hospitality students: Implications for human resource management. In C. Bagnoli, C. Mio, A. Garlatti, \& M. Massaro (Eds.), Proceedings of the 8th European Conference on Intellectual Capital (pp. 95-103). London: Academic Conferences and Publishing International Limited.

GUS Gdańsk. (2017). Edukacja w województwie pomorskim w roku szkolnym 2016/2017. Gdańsk. Retrieved from http://gdansk.stat.gov.pl/ publikacje-i-foldery/edukacja/edukacja-w-wojewodztwie-pomorskimw-roku-szkolnym-20162017,4,13.html.

GUS Szczecin. (2016). Rocznik statystyczny gospodarki morskiej. Szczecin. Retrieved from https://stat.gov.pl/obszary-tematyczne/rocznikistatystyczne/roczniki-statystyczne/rocznik-statystyczny-gospodarkimorskiej-2017,11,10.html

Hartmann, R. (1986). Tourism, seasonality and social change. Leisure Studies, 5(1), 25-33. https://doi.org/10.1080/02614368600390021

Higham, J., \& Hinch, T. (2002). Tourism, sport and seasons: The challenges and potential of overcoming seasonality in the sport and tourism sectors. 
Tourism Management, 23(2), 175-185. https://doi.org/10.1016/S02615177(01)00046-2

Holloway, J.C. (1994). The Hospitality Sector: Accommodation and Catering Services. London: Pitman Publishing Ltd.

Huang, R. (2013). International experience and graduate employability: Perceptions of Chinese international students in the UK. Journal of Hospitality, Leisure, Sport \& Tourism Education, 13, 87-96. https://doi. org/10.1016/j.jhlste.2013.07.001

Hylleberg, S. (1992). General introduction. In S. Hylleberg (Ed.), Modelling Seasonality (pp. 3-14). Oxford: Oxford University Press.

Jang, S. (Shawn). (2004). Mitigating tourism seasonality: A quantitative approach. Annals of Tourism Research, 31(4), 819-836. https://doi. org/10.1016/j.annals.2004.02.007

Jiang, B., \& Tribe, J. (2009). Tourism jobs - short-lived professions': Student attitudes towards tourism careers in China. Journal of Hospitality, Leisure, Sport and Tourism Education, 8(1), 4-19. https://doi.org/10.3794/ johlste.81.168

Kamari, M.N. (2004). Hospitality graduates: An employability model TEAM. Journal of Hospitality \& Tourism, 1(1), 22-41.

Kizielewicz, J., \& Luković, T. (2015). Negative impact of cruise tourism development on local community and the environment. In A. Weintrit \& T. Neuman (Eds.), Information, Communication and Environment: Marine Navigation and Safety of Sea Transportation (pp. 243-250). London: Taylor \& Francis Group.

Ko, W.-H. (2012). The relationships among professional competence, job satisfaction and career development confidence for chefs in Taiwan. International Journal of Hospitality Management, 31(3), 1004-1011. https://doi.org/10.1016/j.ijhm.2011.12.004

Koenig-Lewis, N., \& Bischoff, E.E. (2005). Seasonality research: The state of the art. International Journal of Tourism Research, 7(4-5), 201-219. https://doi.org/10.1002/jtr.531

Kondracki, J. (2014). Geografia regionalna Polski. Warszawa: Wydawnictwo Naukowe. PWN.

Kożuchowski, K. (2014). Bilans cieplny i zmiany temperatury. In K. Kożuchowski (Ed.), Meteorologia i Klimatologia. Warszawa: Wydawnictwo Naukowe. PWN.

Kusluvan, S. (2003). Characteristics of employment and human resource management in the tourism and hospitality industry. In S. Kusluvan (Ed.), Managing Employee Attitudes and Behaviors in the Tourism and Hospitality Industry (pp. 3-24). New York, NY: Nova Science Publishers, Inc.

Kusluvan, S., \& Kusluvan, Z. (2000). Perceptions and attitudes of undergraduate tourism students towards working in the tourism industry in Turkey. Tourism Management, 21(3), 251-269. https://doi.org/10.1016/S02615177(99)00057-6 
Kusluvan, S., \& Kusluvan, Z. (2003). Perceptions and attitudes of undergraduate tourism students towards working in the tourism and hospitality industry in a developing economy. In S. Kusluvan (Ed.), Managing Employee Attitudes and Behaviors in the Tourism and Hospitality Industry (pp. 7798). New York, NY: Nova Science Publishers, Inc.

Kwok, L., Adams, C.R., \& Feng, D. (2012). A comparison of graduating seniors who receive job offers and those who do not according to hospitality recruiters' selection criteria. International Journal of Hospitality Management, 31(2), 500-510. https://doi.org/10.1016/j. ijhm.2011.07.008

Lam, T., \& Ching, L. (2007). An exploratory study of an internship program: The case of Hong Kong students. International Journal of Hospitality Management, 26(2), 336-351. https://doi.org/10.1016/j. ijhm.2006.01.001

Lewis, R.A. (2015). Generation $Y$ at work: Insight from experiences in the hotel sector. International Journal of Business and Management, III(1), 1-17. https://doi.org/10.20472/BM.2015.3.1.001

Lu, T. (Ying), \& Adler, H. (2009). Career goals and expectations of hospitality and tourism students in China. Journal of Teaching in Travel \& Tourism, 9(1-2), 63-80. https://doi.org/10.1080/15313220903041972

Lucas, R., \& Ralston, L. (1996). Part-time student labour: Strategic choice or pragmatic response? International Journal of Contemporary Hospitality Management,8(2),21-24.https://doi.org/10.1108/09596119610111703

Lundberg, D.E., Krishamoorthy, M., \& Stavenga, M.H. (1995). Tourism Economics. Canada: John Wiley and Sons Inc.

Martin, E., \& McCabe, S. (2007). Part-time work and postgraduate students: Developing the skills for employment? The Journal of Hospitality Leisure Sport and Tourism, 6(2), 29-40. https://doi.org/10.3794/johlste.62.133

Mizerski, W., \& Żukowski, J. (Eds.). (2014). Tablice Geograficzne. Warszawa: Grupa Wydawnicza Adamantan.

Ng, E.S.W., Schweitzer, L., \& Lyons, S.T. (2010). New Generation, great expectations: A field study of the Millennial Generation. Journal of Business and Psychology, 25(2), 281-292. https://doi.org/10.1007/ s10869-010-9159-4

Nunnally, J.C. (1978). Psychometric Theory. New York, NY: McGraw-Hill.

Özbağ, G.K., Ceyhun, G.Ç., \& Çekmecelioğlu, H.G. (2014). The moderating effects of motivating job characteristics on the relationship between burnout and turnover intention. Procedia - Social and Behavioral Sciences, 150, 438-446. https://doi.org/10.1016/j.sbspro.2014.09.048

Pang, S.F.H., McKercher, B., \& Prideaux, B. (2013). Climate change and tourism: An overview. Asia Pacific Journal of Tourism Research, 18(1/2), 4-20. https://doi.org/10.1080/10941665.2012.688509

Richardson, S. (2008). Undergraduate tourism and hospitality students attitudes toward a career in the industry: A preliminary investigation. 
Journal of Teaching in Travel \& Tourism, 8(1), 23-46. https://doi. org $/ 10.1080 / 15313220802410112$

Richardson, S., \& Butler, G. (2012). Attitudes of Malaysian tourism and hospitality students' towards a career in the industry. Asia Pacific Journal of Tourism Research, 17(3), 262-276. https://doi.org/10.1080/1094166 5.2011 .625430

Richardson, S., \& Thomas, N.J. (2012). Utilising Generation Y: United States hospitality and tourism students' perceptions of careers in the industry. Journal of Hospitality and Tourism Management, 19(1), 102-114. https:// doi.org/10.1017/jht.2012.12

Roney, S.A., \& Öztin, P. (2007). Career perceptions of undergraduate tourism students: A case study in Turkey. The Journal of Hospitality Leisure Sport and Tourism, 6(1), 4-17. https://doi.org/10.3794/johlste.61.118

Shin, S.-H., \& Lee, T.J. (2011). Degree of motivation of international hospitality students in their work place. The Journal of Hospitality Leisure Sport and Tourism, 10(1), 135-144. https://doi.org/10.3794/johlste.101.281

Sibson, R. (2011). Career choice perceptions of undergraduate event, sport and recreation management students: Australian case study. The Journal of Hospitality Leisure Sport and Tourism, 10(2), 50-60. https://doi. org/10.3794/johlste.102.371

Sims, W.J. (2003). Managing labour turnover in the tourism industry. In S. Kusluvan (Ed.), Managing Employee Attitudes and Behaviors in the Tourism and Hospitality Industry (pp. 545-557). New York, NY: Nova Science Publishers, Inc.

Studzieniecki, T. (2016). The development of cross-border cooperation in an EU macroregion - a case study of the Baltic Sea Region. Procedia Economics and Finance, 39, 235-241. https://doi.org/10.1016/S22125671(16)30318-5

Suwa, M. (2014). Pokolenie $Y$ na polskim rynku pracy. In A. RogozińskaPawełczyk (Ed.), Pokolenia na Rynku Pracy (pp. 65-84). Łódź: Wyd. Uniwersytetu Łódzkiego.

Szelągowska-Rudzka, K. (2014). Partycypacja bezpośrednia pracowników jako przykład innowacji organizacyjnej. In A. Oniszczuk-Jastrząbek \& T. Gutowski (Eds.), Przedsiębiorstwo w Otoczeniu Globalnym (pp. 216-219). Gdańsk: Instytut Transportu i Handlu Morskiego, Uniwersytet Gdański.

Tan, Z.M.A., Baharun, N., Wazir, N.M., Ngelambong, A.A., Ali, N.M., Ghazali, N., \& Tarmazi, S.A.A. (2016). Graduates' perception on the factors affecting commitment to pursue career in the hospitality industry. Procedia Social and Behavioral Sciences, 224, 416-420. https://doi.org/10.1016/j. sbspro.2016.05.410

Teng, C.-C. (2008). The effects of personality traits and attitudes on student uptake in hospitality employment. International Journal of Hospitality Management, 27(1), 76-86. https://doi.org/10.1016/j.ijhm.2007.07.007 Tepeci, M., \& Bartlett, A.L.B. (2002). The hospitality industry culture profile: A measure of individual values, organizational culture, and person- 
organization fit as predictors of job satisfaction and behavioral intentions. International Journal of Hospitality Management, 21(2), 151-170. https://doi.org/10.1016/S0278-4319(01)00035-4

Tesone, D. (2010). Principles of Management for the Hospitality Industry. Burlington, MA: Elsevier/ Butterworth-Heinemann.

Wall, G., \& Mathieson, A. (2006). Tourism: Change, Impacts and Opportunities. Harlow: Pearson Education Limited.

Waśniewska, A., \& Olszewska, K. (2016). Determinants of the demand for higher education services in selected EU countries. In Z. Primorac, C. Bussoli, \& N. Recker (Eds.), Economic and Social Development (Book of Proceedings), 16th International Scientific Conference on Economic and Social Development - "Legal Challenges of Modern World" (pp. 403412). Varazdin: Varazdin Development and Entrepreneurship Agency, Faculty of Law, University of Split, University North, Koprivnica. Retrieved from https://www.esd-conference.com/upload/book_of_proceedings/ esd_Book_of_Proceedings_Split_2016_Online.pdf

Witt, S.F., \& Moutinho, L. (Eds.). (1995). Tourism Marketing and Management Handbook. London - New York, NY: Prentice Hall.

World Travel \& Tourism Council. (2015a). Global Talent Trends and Issues for the Travel \& Tourism Sector. Retrieved from http://www.wttc.org/-/ media/files/reports/policy\%20research/global\%20talent\%20trends\%20 report\%20-\%20web.pdf /05.10.2017/

World Travel \& Tourism Council. (2015b). Travel \& Tourism. Economic Impact 2015. Poland. London. Retrieved from https://www.wttc.org/-/media/ files/reports/economic-impact-research/countries-2015/poland2015.pdf

World Travel \& Tourism Council. (2017a). Travel \& Tourism Economic Impact 2017. Poland. Retrieved from https://www.wttc.org/-/media/files/ reports/economic-impact-research/countries-2017/poland2017.pdf /08.12.2017/

World Travel \& Tourism Council. (2017b). Travel \& Tourism Global Economic Impact \& Issues 2017. Retrieved from https://www.wttc.org/-/media/ files/reports/economic-impact-research/2017-documents/globaleconomic-impact-and-issues-2017.pdf

Yan, M., \& Wall, G. (2003). Disaggregating visitor flows: The example of China. Tourism Analysis, 7(3), 191-205. https://doi. org/10.3727/108354203108750049

\begin{abstract}
Abstrakt
W ostatnich latach wiele krajów odnotowało szybki rozwój turystyki, który jest postrzegany, jako swoisty "motor" wzrostu gospodarczego i rozwoju społecznego. $Z$ drugiej strony, mimo, iż turystyka generuje wiele nowych miejsc pracy, wciq̨ż wiele krajów boryka się z problemami zwiqzanymi z pozyskaniem i zatrzymaniem wykwalifikowanych kadr. Problem ten potęguje fakt, że wielu absolwentów, nie podejmuje zatrudnienia w turystyce po ukończeniu studiów, wskazujqc na specyficzny charakter
\end{abstract}


tej pracy, w tym jej sezonowość. Stąd biorq̨c pod uwagę powyższe, celem niniejszych badań było rozpoznanie postaw studentów specjalności zwiqzanych z turystykq i/lub hotelarstwem (T\&H), wobec problemu sezonowości zatrudnienia w turystyce oraz zbadanie czy istnieje zależność pomiędzy postrzeganiem sezonowości a aspiracjami studentów wobec zatrudnienia w branży turystycznej po zakończeniu studiów. Badanie przeprowadzono wśród studentów wyższych uczelni zlokalizowanych w północnej Polsce (Region Południowego Bałtyku), która w sposób szczególny doświadcza problemu sezonowości w turystyce. W rezultacie przeprowadzonych badań ankietowych uzyskano 171 poprawnie wypełnionych kwestionariuszy. Rezultaty badań ukazały, że sezonowość zatrudnienia $w$ branży turystycznej jest raczej pozytywnie postrzegana przez badanych. Istnieje także statystycznie istotna zależność pomiędzy percepcja sezonowości a aspiracjami zawodowymi studentów. W szczególności, respondenci, którzy postrzegali zjawisko sezonowości pozytywnie, również chętniej deklarowali swojq intencję zatrudnienia $w$ branży turystycznej po zakończeniu studiów, w przeciwieństwie do badanych, którzy zjawisko to postrzegali negatywnie. Interesujacym jest również, iż studenci, którzy pracowali już sezonowo w turystyce, postrzegali problem sezonowości w bardziej pozytywny sposób, co ukazuje istotnq rolę doświadczenia pracy w kształtowaniu pozytywnych postaw przyszłych kadr sektora turystycznego wobec pracy $w$ branży.

Słowa kluczowe: Region Południowego Bałtyku, turystyka, sezonowość, aspiracje zawodowe, studenci.

\section{Biographical notes}

Aleksandra Grobelna, Ph.D. in the field of economy; an Assistant Professor at Gdynia Maritime University (Poland) at the Faculty of Entrepreneurship and Quality Science; a member of the Polish Economics Society. Her scientific studies focus particularly on human resource management and service quality management in Tourism and Hospitality (T\&H). She regularly publishes peer-reviewed academic papers in quality journals and presents her research results at national and international scientific conferences. In her research projects, she cooperates closely with T\&H business practitioners helping them to solve topical management problems.

Katarzyna Skrzeszewska, Ph.D. in the field of economy; an Assistant Professor at Gdynia Maritime University (Poland) at the Faculty of Entrepreneurship and Quality Science. A member of the Polish Economics Society; Polish Nautological Society, WISTA Poland. Her scientific studies focus on policy and strategy for regional development, maritime policy, and the maritime labor market. 